\title{
Transesterification of Vegetable Oils: a Review
}

\author{
Ulf Schuchardt ${ }^{a}$, Ricardo Sercheli ${ }^{a}$, and Rogério Matheus Vargas ${ }^{b}$ \\ ${ }^{a}$ Instituto de Química, Universidade Estadual de Campinas, C.P. 6154, \\ 13083-970 Campinas - SP, Brazil \\ ${ }^{b}$ Instituto de Química, Universidade Federal da Bahia, Campus de Ondina, \\ 40170-290 Salvador - BA, Brazil
}

Received: May 9, 1997

\begin{abstract}
A transesterificação de óleos vegetais com metanol, bem como as principais aplicações de ésteres metílicos de ácidos graxos, são revisadas. São descritos os aspectos gerais desse processo e a aplicabilidade de diferentes tipos de catalisadores (ácidos, hidróxidos, alcóxidos e carbonatos de metais alcalinos, enzimas e bases não-iônicas, como aminas, amidinas, guanidinas e triamino(imino)fosforanos). Enfoque especial é dado às guanidinas, que podem ser facilmente heterogeneizadas em polímeros orgânicos. No entanto, as bases ancoradas lixiviam dos polímeros. Novas estratégias para a obtenção de guanidinas heterogeneizadas mais resistentes à lixiviação são propostas. Finalmente, são descritas várias aplicações para ésteres de ácidos graxos, obtidos por transesterificação de óleos vegetais.

The transesterification of vegetable oils with methanol as well as the main uses of the fatty acid methyl esters are reviewed. The general aspects of this process and the applicability of different types of catalysts (acids, alkaline metal hydroxides, alkoxides and carbonates, enzymes and non-ionic bases, such as amines, amidines, guanidines and triamino(imino)phosphoranes) are described. Special attention is given to guanidines, which can be easily heterogenized on organic polymers. However, the anchored catalysts show leaching problems. New strategies to obtain non-leaching guanidine-containing catalysts are proposed. Finally, several applications of fatty acid esters, obtained by transesterification of vegetable oils, are described.
\end{abstract}

Keywords: transesterification, fatty acid methyl esters, non-ionic bases, heterogenization

\section{General Aspects of Transesterification}

Transesterification is the general term used to describe the important class of organic reactions where an ester is transformed into another through interchange of the alkoxy moiety. When the original ester is reacted with an alcohol, the transesterification process is called alcoholysis (Scheme 1) ${ }^{1}$. In this review, the term transesterification will be used as synonymous for alcoholysis of carboxylic esters, in agreement with most publications in this field. The transesterification is an equilibrium reaction and the transformation occurs essentially by mixing the reactants. However, the presence of a catalyst (typically a strong acid or

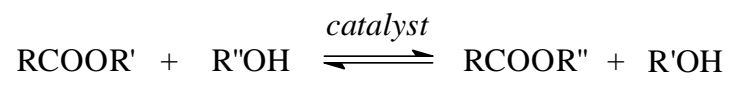

Scheme 1. General equation for a transesterification reaction. base) accelerates considerably the adjustment of the equilibrium. In order to achieve a high yield of the ester, the alcohol has to be used in excess.

The applicability of transesterification is not restricted to laboratory scale. Several relevant industrial processes use this reaction to produce different types of compounds ${ }^{1}$. An example is the production of PET (polyethylene terephthalate), which involves a step where dimethylterephthalate is transesterified with ethylene glycol in the presence of zinc acetate as catalyst (Scheme 2$)^{2}$. Furthermore, a large number of acrylic acid derivatives is produced by transesterification of methyl acrylate with different alcohols, in the presence of acid catalysts ${ }^{3-6}$.

If the alcohol and the ester groups are present in the same molecule simple lactones ${ }^{7,8}$ or macrocycles ${ }^{9-10}$ are formed by an intramolecular transesterification, as shown 

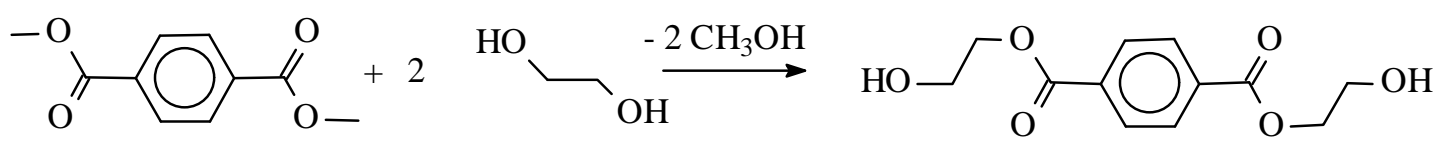

Scheme 2. Transesterification of dimethylterephthalate with ethylene glycol.

in Scheme 3. Further transesterification reactions can be found in the literature, in which metal alkoxides ${ }^{11-16}$, aluminum isopropoxide ${ }^{17-19}$, tetraalkoxytitanium compounds $^{20-22}$ and organotin alkoxides ${ }^{23,24}$ are applied as catalysts.

\section{Transesterification of Vegetable Oils}

In the transesterification of vegetable oils, a triglyceride reacts with an alcohol in the presence of a strong acid or base, producing a mixture of fatty acids alkyl esters and glycerol $^{25,26}$ (Scheme 4). The overall process is a sequence of three consecutive and reversible reactions, in which diand monoglycerides are formed as intermediates ${ }^{26}$. The stoichiometric reaction requires $1 \mathrm{~mol}$ of a triglyceride and $3 \mathrm{~mol}$ of the alcohol. However, an excess of the alcohol is used to increase the yields of the alkyl esters and to allow its phase separation from the glycerol formed.

Several aspects, including the type of catalyst (alkaline or acid), alcohol/vegetable oil molar ratio, temperature, purity of the reactants (mainly water content) and free fatty acid content have an influence on the course of the transesterification and will be discussed below, based on the type of catalyst used.

\section{Acid-Catalyzed Processes}

The transesterification process is catalyzed by $\mathrm{Br} \emptyset \mathrm{n}-$ sted acids, preferably by sulfonic ${ }^{27}$ and sulfuric ac$\mathrm{ids}^{26,28,29}$. These catalysts give very high yields in alkyl esters, but the reactions are slow, requiring, tipically, temperatures above $100^{\circ} \mathrm{C}$ and more than $3 \mathrm{~h}$ to reach complete conversion ${ }^{30}$. Pryde et al ${ }^{26}$ showed that the methanolysis of soybean oil, in the presence of $1 \mathrm{~mol} \%$ of $\mathrm{H}_{2} \mathrm{SO}_{4}$, with an alcohol/oil molar ratio of $30: 1$ at $65{ }^{\circ} \mathrm{C}$, takes $50 \mathrm{~h}$ to reach complete conversion of the vegetable oil (> 99\%), while the butanolysis $\left(\right.$ at $117^{\circ} \mathrm{C}$ ) and ethanolysis $\left(\right.$ at $78^{\circ} \mathrm{C}$ ), using the same quantities of catalyst and alcohol, take 3 and $18 \mathrm{~h}$, respectively.

The alcohol/vegetable oil molar ratio is one of the main factors that influences the transesterification. An excess of the alcohol favors the formation of the products. On the

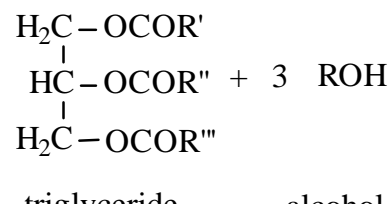

Scheme 4. Transesterification of vegetable oils.
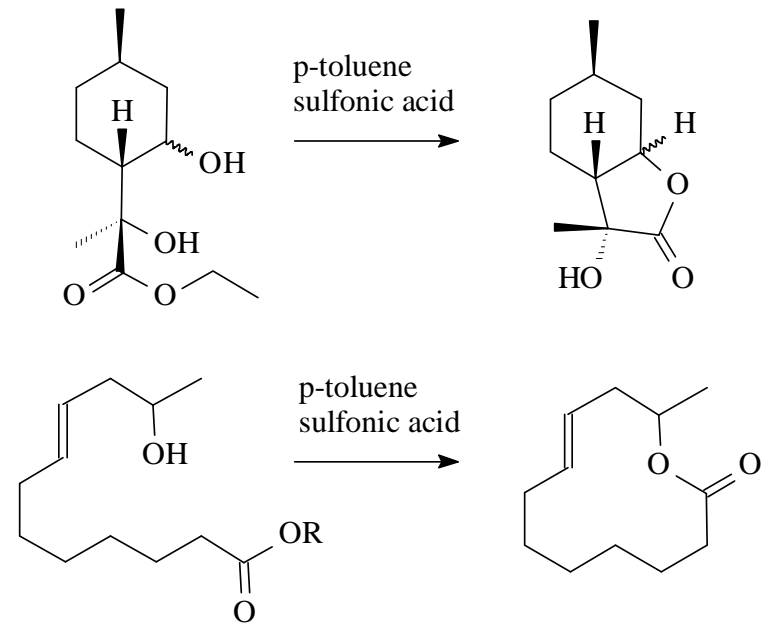

Scheme 3. Examples of intramolecular transesterification reactions, forming lactones or macrocycles.

other hand, an excessive amount of alcohol makes the recovery of the glycerol difficult, so that the ideal alcohol/oil ratio has to be established empirically, considering each individual process.

The mechanism of the acid-catalyzed transesterification of vegetable oils is shown in Scheme 5, for a monoglyceride. However, it can be extended to di- and triglycerides ${ }^{31}$. The protonation of the carbonyl group of the ester leads to the carbocation II which, after a nucleophilic attack of the alcohol, produces the tetrahedral intermediate III, which eliminates glycerol to form the new ester $\mathrm{IV}$, and to regenerate the catalyst $\mathrm{H}^{+}$.

According to this mechanism, carboxylic acids can be formed by reaction of the carbocation II with water present in the reaction mixture. This suggests that an acid-catalyzed transesterification should be carried out in the absence of water, in order to avoid the competitive formation of carboxylic acids which reduce the yields of alkyl esters.

\section{Base-Catalyzed Processes}

The base-catalyzed transesterification of vegetable oils proceeds faster than the acid-catalyzed reaction ${ }^{26,30}$. Due

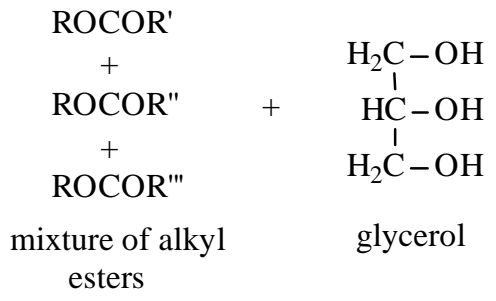




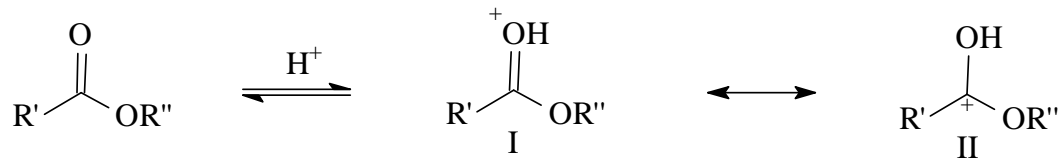

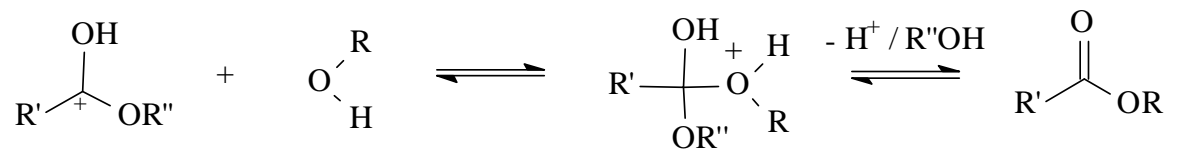

$$
\begin{aligned}
\mathrm{R}^{\prime \prime} & =\left[\begin{array}{ll}
\mathrm{O}- \\
\mathrm{OH} & ; \text { glyceride } \\
\mathrm{OH}
\end{array}\right. \\
\mathrm{R}^{\prime} & =\text { carbon chain of the fatty acid } \\
\mathrm{R} & =\text { alkyl group of the alcohol }
\end{aligned}
$$

Scheme 5. Mechanism of the acid-catalyzed transesterification of vegetable oils.

$$
\mathrm{ROH}+\mathrm{B} \rightleftharpoons \mathrm{RO}^{-}+\mathrm{BH}^{+}
$$
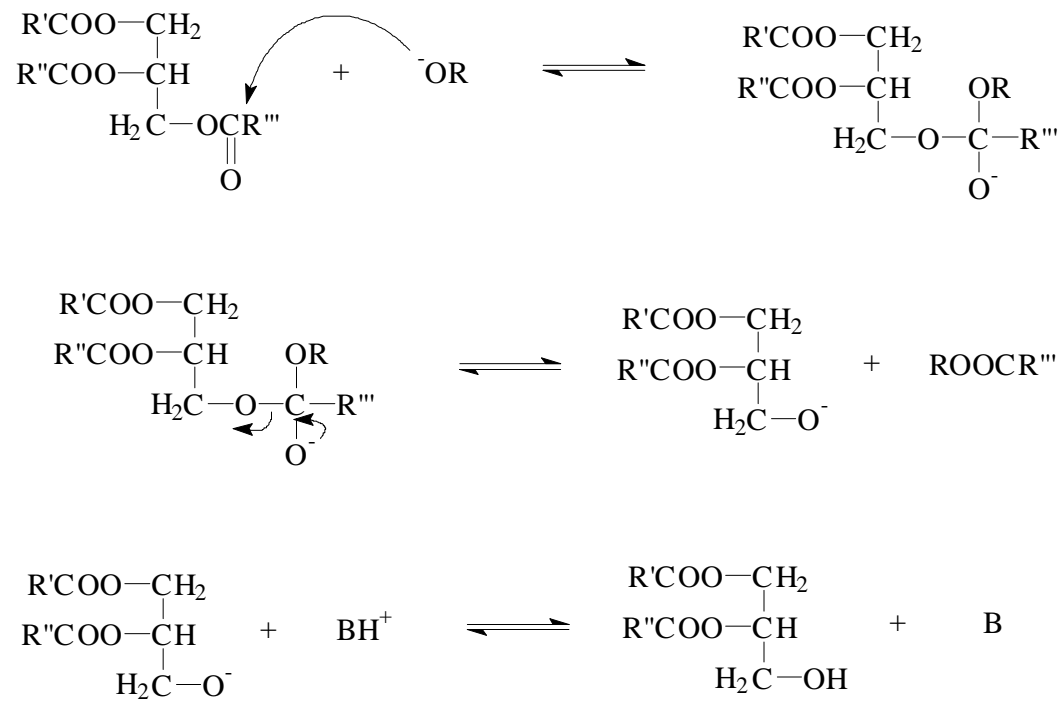

Scheme 6. Mechanism of the base-catalyzed transesterification of vegetable oils.

to this reason, together with the fact that the alkaline catalysts are less corrosives than acidic compounds, industrial processes usually favor base catalysts, such as alkaline metal alkoxides ${ }^{26,30,32}$ and hydroxides ${ }^{29,33-36}$ as well as sodium or potassium carbonates ${ }^{37-39}$.

The mechanism of the base-catalyzed transesterification of vegetable oils is shown in Scheme 6. The first step (Eq. 1) is the reaction of the base with the alcohol, producing an alkoxide and the protonated catalyst. The nucleophilic attack of the alkoxide at the carbonyl group of the triglyceride generates a tetrahedral intermediate (Eq. $2)^{11,40}$, from which the alkyl ester and the corresponding anion of the diglyceride are formed (Eq. 3). The latter deprotonates the catalyst, thus regenerating the active species (Eq. 4), which is now able to react with a second molecule of the alcohol, starting another catalytic cycle. Diglycerides and monoglycerides are converted by the same mechanism to a mixture of alkyl esters and glycerol.

Alkaline metal alkoxides (as $\mathrm{CH}_{3} \mathrm{ONa}$ for the methanolysis) are the most active catalysts, since they give very high yields (> 98\%) in short reaction times $(30 \mathrm{~min})$ even if they are applied at low molar concentrations $(0.5$ $\mathrm{mol} \%$ ). However, they require the absence of water which makes them inappropriate for typical industrial processes $^{30}$. Alkaline metal hydroxides $(\mathrm{KOH}$ and $\mathrm{NaOH})$ are cheaper than metal alkoxides, but less active. Nevertheless, they are a good alternative since they can give the same high conversions of vegetable oils just by increasing the catalyst concentration to 1 or $2 \mathrm{~mol} \%$. However, even if a water-free alcohol/oil mixture is used, some water is pro- 
duced in the system by the reaction of the hydroxide with the alcohol. The presence of water gives rise to hydrolysis of some of the produced ester, with consequent soap formation (Scheme 7). This undesirable saponification reaction reduces the ester yields and considerably difficults the recovery of the glycerol due to the formation of emulsions $^{30}$.

Potassium carbonate, used in a concentration of 2 or 3 mol\% gives high yields of fatty acid alkyl esters and reduces the soap formation ${ }^{38}$. This can be explained by the formation of bicarbonate instead of water (Scheme 8), which does not hydrolyse the esters.

\section{Lipase-Catalyzed Processes}

Due to their ready availability and the ease with which they can be handled, hydrolytic enzymes have been widely applied in organic synthesis. They do not require any coenzymes, are reasonably stable, and often tolerate organic solvents. Their potential for regioselective and especially for enantioselective synthesis makes them valuable tools ${ }^{41}$.

Although the enzyme-catalyzed transesterification processes are not yet commercially developed, new results have been reported in recent articles and patents ${ }^{42-48}$. The common aspects of these studies consist in optimizing the reaction conditions (solvent, temperature, $\mathrm{pH}$, type of microorganism which generates the enzyme, etc) in order to establish suitable characteristics for an industrial application. However, the reaction yields as well as the reaction times are still unfavorable compared to the base-catalyzed reaction systems.

\section{Non-Ionic Base-Catalyzed Processes}

In order to obtain milder reaction conditions and to simplify manipulations, a great number of organic bases has been developed and used as catalyst or reactant for organic syntheses. Among these bases, amines such as triethylamine ${ }^{49,50}$, piperidine ${ }^{49}, 1,2,2,6,6$-pentamethylpi-

$$
\begin{aligned}
& \mathrm{R}_{\mathrm{OR}}^{\prime}=\text { carbon chain of the fatty acid } \\
& \mathrm{R}=\text { alkyl group of the alcohol }
\end{aligned}
$$

Scheme 7. Saponification reaction of the produced fatty acid alkyl esters.

$$
\begin{aligned}
& \mathrm{K}_{2} \mathrm{CO}_{3}+\mathrm{ROH} \rightleftharpoons \mathrm{ROK}+\mathrm{KHCO}_{3} \\
& \mathrm{R}=\text { alkyl group of the alcohol }
\end{aligned}
$$

Scheme 8. Reaction of potassium carbonate with the alcohol. peridine $^{49,51}$, pyridine ${ }^{49,50,51}, 2,6$-di-tert-butylpyridine ${ }^{49,51}$ and 4-dimethyl-aminopyridine ${ }^{1,52}$ (DMAP); amidines such as 1,8-diazabicyclo[5.4.0]undec-7-ene 1,49,50,51 $^{\text {DBU) and }}$ 1,5-diazabicyclo[4.3.0]non-5-ene ${ }^{49,51,53}$ (DBN); guanidines such as 1,5,7-triazabicyclo[4.4.0]dec-5-ene ${ }^{50,54}$ (TBD), 1,1,3,3-tetramethylguanidine ${ }^{55,56,57}$ (TMG), 1,1,2,3,3-pentabutylguanidine $^{58}$ (PBG), 1,3-diphenylguanidine ${ }^{59}, 1,2,3$ triphenylguanidine ${ }^{60,61}$ and amino- and nitroguanidines ${ }^{62}$; triamino(imino)phosphoranes such as tert-butylimino-2diethylamino-1,3-dimethyl-perhydro-1,3,2- diazaphosphorane $^{51}$ (BEMP) and tris(dimethylamino)methyliminophosphorane $^{51}\left(\mathrm{Me}_{7} \mathrm{P}\right)$, shown in Scheme 9, are frequently used in organic synthesis.

The activity and efficiency of such non-ionic bases as catalysts for the transesterification of vegetable oils were studied. In a first series of studies, the catalytic activity of some guanidines was compared to that observed using other bases such as the amidines DBU and DBN, and the triamino(imino)phosphoranes BEMP and $\mathrm{Me}_{7} \mathrm{P}^{63}$. It was observed that TBD, even if applied at only $1 \mathrm{~mol} \%$, produces more than $90 \%$ of methyl esters after $1 \mathrm{~h}$. Using the other bases, under the same experimental conditions, the yields were not higher than $66 \%$ (Table 1). The order of the catalytic activity is not directly related to the relative basicity of these compounds, since BEMP and $\mathrm{Me}_{7} \mathrm{P}$ should be the more efficient catalysts, followed by TBD. However, the guanidines are more active catalysts and the activity follows their relative basicity.

According to the observed results and to the mechanism of the base-catalyzed transesterification (Scheme 6), it seems that the good performance of TBD, when compared to $\mathrm{BEMP}$ and $\mathrm{Me}_{7} \mathrm{P}$, is related to its kinetic activity. The catalytic site (unshared electron pair of the $\mathrm{sp}^{2} \mathrm{~N}$ ) of TBD is practically unhindered (Scheme 10), allowing an easy access of the methanol for proton transfer, while the steric

Table 1. Comparison of the catalytic activity of some guanidines, amidines and triamino(imimo)phosphoranes in the transesterification of rapeseed oil with methanol.

\begin{tabular}{lccc}
\hline Catalyst & $\begin{array}{c}\text { Relative } \\
\text { basicity }^{51}\end{array}$ & $\begin{array}{c}\mathrm{pKa} \\
\left(\mathrm{CH}_{3} \mathrm{CN}\right)^{49}\end{array}$ & $\begin{array}{c}\text { Yield (\%) } \\
\text { after } 1 \mathrm{~h}^{\mathrm{a}}\end{array}$ \\
\hline TBD & 150 & 25.9 & 91 \\
BEMP & 6873 & not available & 66 \\
Me7P & 4762 & 27.52 & 63 \\
MTBD & 43.65 & 25.43 & 47 \\
DBU & 3.4 & 24.32 & 32 \\
TMG & 0.95 & 23.30 & 18 \\
DBN & 1 & 23.79 & 4.5 \\
\hline
\end{tabular}

a: conditions: $8.00 \mathrm{~g}(27.2 \mathrm{mmol})$ of rapeseed oil, $2.00 \mathrm{~g}(62.5 \mathrm{mmol})$ of methanol, $1 \mathrm{~mol} \%$ of catalyst, $70{ }^{\circ} \mathrm{C}$. 
<smiles>C1CN=C2NCCCN2C1</smiles>

TBD<smiles>C1CCC2=NCCCN2CC1</smiles>

DBU<smiles>C1CN=C2CCCN2C1</smiles><smiles>CCN(CC)P1(=NC(C)(C)C)N(C)CCCN1C</smiles>

DBN

BEMP<smiles>CN=P(N(C)C)(N(C)C)N(C)C</smiles>

$\mathrm{Me}_{7} \mathrm{P}$<smiles>CN1CCCN2CCCN=C12</smiles>

MTBD<smiles>CCCCCCCCCCCCCCNC(=NC1CCCCC1)N(NC1CCCCC1)C1CCCCC1</smiles>

TCG

Scheme 9. Molecular structures of some non-ionic organic bases.<smiles>C1CN=C2NCCCN2C1</smiles>

TBD

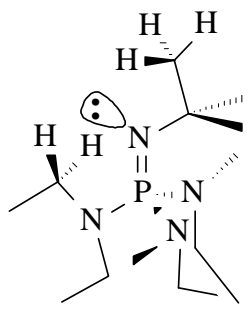

BEMP

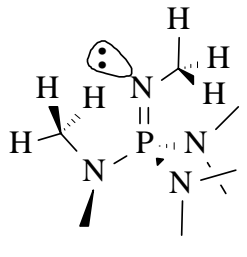

$\mathrm{Me}_{7} \mathrm{P}$

Scheme 10. Steric hindrance of TBD, BEMP and $\mathrm{Me}_{7} \mathrm{P}$.

hindrance shown by the triamino(imino)phosphoranes is so significant that they are practically inert to alkylating agents, such as isopropyl bromide, as well as extremely resistant to react with thionyl chloride and thiophosgene ${ }^{51}$. Other bases such as DMAP, pyridine and triethylamine were also tested. However, even at $5 \mathrm{~mol} \%$, these amines did not give satisfactory yields. DMAP was the most active within this series, producing only $20 \%$ of methyl esters after $1 \mathrm{~h}$.

In a second series of studies, the catalytic activity of TBD was compared to that observed for typical industrial catalysts (e.g. $\mathrm{NaOH}$ and $\left.\mathrm{K}_{2} \mathrm{CO}_{3}\right)^{37-39}$. The results of this study ${ }^{63}$ are shown in Table 2 . The reaction yields obtained with TBD were close to those observed with $\mathrm{NaOH}$ and no undesirable by-products such as soaps (easily formed when alkaline metal hydroxides are used) were observed. When compared to potassium carbonate, TBD was always more active, even at low molar concentrations. Although TBD is less active than sodium methoxide (at only $0.5 \%, \mathrm{CH}_{3} \mathrm{ONa}$ produces more than $98 \%$ of methyl esters after $30 \mathrm{~min}$ ), its use does not require any special condition.
Table 2. Comparison between TBD and the conventional inorganic catalysts.

\begin{tabular}{lc}
\hline Catalyst & Yield $(\%)$ after $1 \mathrm{~h}^{\mathrm{a}}$ \\
\hline $\mathrm{NaOH}(1 \mathrm{~mol} \%)$ & 98.7 \\
$\mathrm{~K}_{2} \mathrm{CO}_{3}(1 \mathrm{~mol} \%)$ & 84.0 \\
$\mathrm{~K}_{2} \mathrm{CO}_{3}(2 \mathrm{~mol} \%)$ & 90.3 \\
$\mathrm{~K}_{2} \mathrm{CO}_{3}(3 \mathrm{~mol} \%)$ & 92.4 \\
$\mathrm{TBD}(1 \mathrm{~mol} \%)$ & 89.0 \\
$\mathrm{TBD}(2 \mathrm{~mol} \%)$ & 91.4 \\
$\mathrm{TBD}(3 \mathrm{~mol} \%)$ & 93.0 \\
\hline
\end{tabular}

a: $8.00 \mathrm{~g}(27.2 \mathrm{mmol})$ of rapeseed oil, $2.00 \mathrm{~g}(62.5 \mathrm{mmol})$ of methanol, $1 \mathrm{~h}, 70{ }^{\circ} \mathrm{C}$

Due to the excellent performance of TBD in the transesterification of vegetable oils, the catalytic activity of other alkylguanidines was also investigated, in order to establish and understand all factors that may affect their catalytic properties. In a third series of studies, the catalytic 
activity of several alkylguanidines was compared ${ }^{64}$. TBD was always the most active, however, 1,3-dicyclohexyl-2-n-octylguanidine (DCOG), 1,1,2,3,3pentamethylguanidine (PMG), 7-methyl-1,5,7-triazabicyclo[4.4.0]dec-5-ene (MTBD) and 1,2,3-tricyclohexylguanidine (TCG), also showed a good catalytic performance $^{64}$. The activity order of the catalysts TBD > TCG > DCOG > MTBD > PMG (Table 3) corresponds to their relative base strength, which is increased by structural factors such as number and type of substituents (cyclic or acyclic chain) $)^{51}$. The excellent performance of DCOG and TCG is also assigned to the high symmetry of their guanidinium cations, as observed earlier for the symmetric 1,2,3trimethylguanidine ${ }^{65}$.

Results obtained in the transesterification of soybean oil with methanol show that 1,2,3,4,5-pentacyclohexyl-

Table 3. Transesterification of rapeseed oil with methanol using the most active alkylguanidines as catalysts.

\begin{tabular}{lccc}
\hline \multicolumn{4}{c}{ Yields (\%) after $1 \mathrm{~h}^{\mathrm{a}}$} \\
\hline Catalyst & $1 \mathrm{~mol} \%$ & $2 \mathrm{~mol} \%$ & $3 \mathrm{~mol} \%$ \\
\hline TBD & 90 & 91 & 93 \\
DCOG & 74 & 80 & 92 \\
TCG & 64 & 91 & 92 \\
MTBD & 47 & 74 & - \\
PMG & 49 & 67 & 90 \\
\hline
\end{tabular}

a: conditions: $8.00 \mathrm{~g}(27.2 \mathrm{mmol})$ of rapeseed oil, $2.00 \mathrm{~g}(62.5 \mathrm{mmol})$ of methanol, $1 \mathrm{~mol} \%$ of catalyst, $70{ }^{\circ} \mathrm{C}$. biguanidine (PCBG) is even more active than TCG, as a $82 \%$ yield of methyl esters is obtained with PCBG after $1 \mathrm{~h}$, compared to $69 \%$ with TCG under the same conditions ${ }^{66}$.

\section{Heterogeneously Catalyzed Processes}

The advantage of using guanidines in the transesterification of vegetable oils is the possibility to heterogenize them on organic polymers. Schuchardt et al. tested principally cellulose and poly(styrene/divinylbenzene), but also polyuretanes and other organic polymers allow the suitable incorporation of guanidines. The heterogenization of guanidines on organic polymers and their use in the transesterification of vegetable oils were described in a patent $^{67}$.

The heterogenization of unsubstituted guanidines can be achieved by their reaction with microcrystalline cellulose activated by cyanuric chloride at the C- 6 position (Scheme 11). After deprotonation of the guanidinium salt formed, the guanidine-containing cellulose shows a slightly reduced activity, compared to guanidine in homogeneous phase, giving a conversion of $30 \%$ after $1 \mathrm{~h}$, when used at $5 \mathrm{~mol} \%{ }^{68}$. This guanidine-containing cellulose was used in a continuous reactor containing $100 \mathrm{~g}$ of the catalyst. An alcohol/oil mixture of 2:1 was pumped at $60{ }^{\circ} \mathrm{C}$ with a rate of $0.48 \mathrm{~L} / \mathrm{h}$. In the first hour the methyl esters were obtained with high yields and the phase separation was quick $^{69}$. After this, however, the reaction was incomplete and the phase separation difficult. This could be due either to leaching of the catalyst or to its irreversible protonation. As no leaching tests were performed, no definite reason can be given at this point.

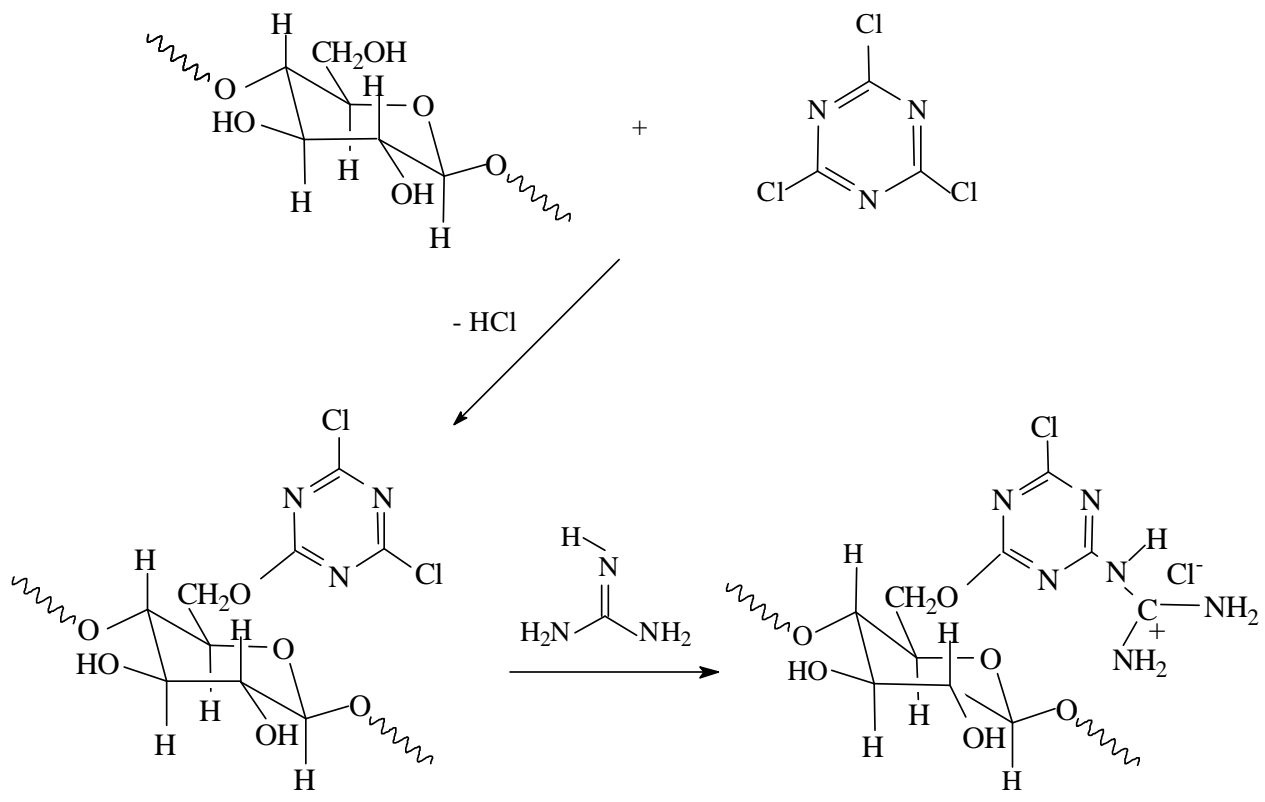

Scheme 11. Heterogenization of guanidine on activated microcrystalline cellulose. 
The catalytic performance of some alkylguanidines heterogenized on different substituted polystyrenes was investigated $^{70}$. The guanidine-containing polymers (Scheme 12) were used in the transesterification of soybean oil with methanol in several consecutive catalytic cycles. The guanidines heterogenized on gel-type poly(styrene/divinylbenzene) with $1 \mathrm{meq} \mathrm{Cl} / \mathrm{g}$ (polymers I and II) showed a slightly lower activity than their homogeneous analogues but allowed the same high conversions after prolonged reaction times. However, they slowly leached from the polymers, allowing only nine catalytic cycles. The guanidines heterogenized on linear polystyrene with the use of a 'spacer-arm' (polymers III, IV), were less active. Polymer V, which is symmetrically substituted showed an activity as high as polymer I. When another methyl group was introduced (polymer VI) its activity was slightly reduced. Furthermore, all polymers with a 'spacer-arm' suffered substitution reactions during the recycling experiments to form inactive hexasubstituted guanidinium compounds. A summary of the catalytic performance of these polymers is shown in Table 4.

The lower activity of the guanidine-containing polymers I and II, when compared to their homogeneous analogues, is probably due to the hydrophobicity of the polymer chain which reduces the concentration of the methanol at the active sites. However, at prolonged reaction times, the efficiency of the anchored catalysts is practically the same. The use of a 'spacer-arm' (polymers III-VI) was expected to improve the performance of the heterogenized catalyst. However, polymer IV showed the same activity as

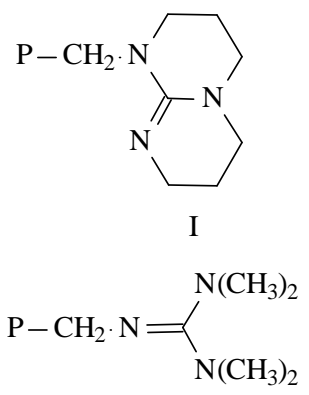

II

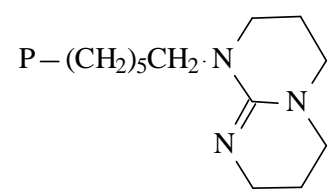

III polymer II and polymer III was even less active than polymer $\mathrm{I}^{70}$.

Despite less active than their homogeneous analogues, all polymer-containing guanidines could be reused in several consecutive reaction cycles ${ }^{70}$. However, a loss of activity was observed, mainly due to leaching of the anchored base from the polymers, as mentioned above. Polymers I and II have the guanidine moiety bound to the benzylic $\mathrm{CH}_{2}$ group of the polystyrene. After the protonation of the base, the electrophilic character of the methylene group is in-

Table 4. Total turnover numbers and turnover frequencies (after $1 \mathrm{~h}$ ) observed with guanidine-containing polymers in the transesterification of soybean oil with methanol.

\begin{tabular}{|c|c|c|}
\hline Catalyst & $\begin{array}{c}\text { total turnover } \\
\text { number }{ }^{\mathrm{a}, \mathrm{b}} \\
\text { (number of cycles) }\end{array}$ & $\begin{array}{l}\text { turnover frequency } \\
\qquad\left(\mathrm{h}^{-1}\right)^{\mathrm{c}}\end{array}$ \\
\hline I & $124(9)$ & 15 \\
\hline II & $118(9)$ & 12 \\
\hline III & $36(5)$ & 13 \\
\hline IV & $30(4)$ & 12 \\
\hline $\mathrm{V}$ & $84(6)$ & 15 \\
\hline VI & $42(7)$ & 14 \\
\hline
\end{tabular}

a: turnover number: mol of products/ $\mathrm{mol}$ of catalyst.

b: conditions: 1 eq. of soybean oil, 6.9 eq. of methanol, $5 \mathrm{~mol} \%$ of base, $70{ }^{\circ} \mathrm{C}$. c: turnover frequency: turnover number/ reaction time.

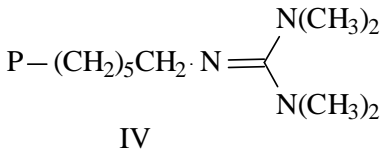

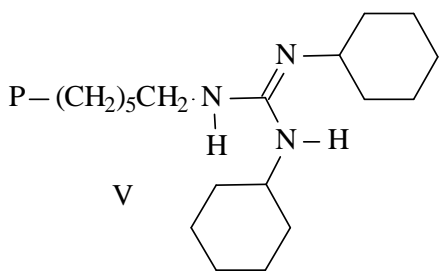<smiles>FCCCCCCNC(=NC1CCCCC1)NC1CCCCC1</smiles>

$$
\mathrm{P}=\text { polymer chain }
$$

Scheme 12. Molecular structures of some guanidine-containing polystyrenes. 
creased, thus becoming more susceptible to nucleophilic attack by methoxide ions present in the reaction medium. This attack results in the removal of the guanidine moiety from the polymer as shown in Scheme 13. The leaching of the guanidines from the other polymers follows a similar mechanism.

For the polymers containing a 'spacer-arm', there is an additional factor that accelerates the deactivation of the supported catalysts. The anchored bases can react with electrophilic functional groups which are further away on the polymer chain, producing inactive hexasubstituted guanidinium compounds ${ }^{64}$, as shown in Scheme 14. However, it is possible to deprotonate these hexasubstituted guanidinium compounds, which should give doubly anchored active guanidines whose leaching is less probable.

In order to circumvent the leaching of the guanidines from the polymers, Schuchardt et al. encapsulate TCG by the reaction of dicyclohexylcarbodiimide and cyclohexylamine in the supercages of a hydrophobic Y zeolite. The encapsulated guanidine showed a good catalytic activity in the addition reaction of benzaldehyde to acetone ${ }^{71}$. However, its activity in the transesterification of vegetable oils is low ( $14 \%$ conversion after $5 \mathrm{~h}^{72}$ ), as the diffusion of the triglycerides through the channels of the Y zeolite is slow due to steric hindrance.

\section{Fatty Acid Alkyl Esters as Feedstocks for In- dustry}

Fatty acid methyl esters can be transformed into a lot of useful chemicals, and raw materials for further synthesis ${ }^{73}$, as shown in Scheme 15. The alkanolamides, whose production consumes the major part of the methyl esters produced in the world, have a direct application as non-ionic surfactants, emulsifying, thickening and plastifying agents, etc ${ }^{73}$. The fatty alcohols are applied as pharmaceutical and cosmetics additives $\left(\mathrm{C}_{16}-\mathrm{C}_{18}\right)^{73}$, as well as lubricants and plastifying agents $\left(\mathrm{C}_{6}-\mathrm{C}_{12}\right)$, depending on the length of their carbon chain. The isopropyl esters are also applied as plastifying agents and emollients. However, they can not be produced in a convenient way by esterification of fatty acids, as an azeotrope formed by water and isopropanol avoids the recycling of the alcohol. The fatty acid methyl esters are further used in the manufacture of carbohydrate fatty acid esters (sucrose polyesters), which can be applied as non-ionic surfactants or edible non-calorific oils ${ }^{74-77}$, and can be used as an alternative fuel substitute for diesel engines (biodiesel) ${ }^{28-30,78-80}$. These two applications will be discussed separately.

The glycerol also has important applications, in cosmetics, toothpastes, pharmaceuticals, food, lacquers, plastics,

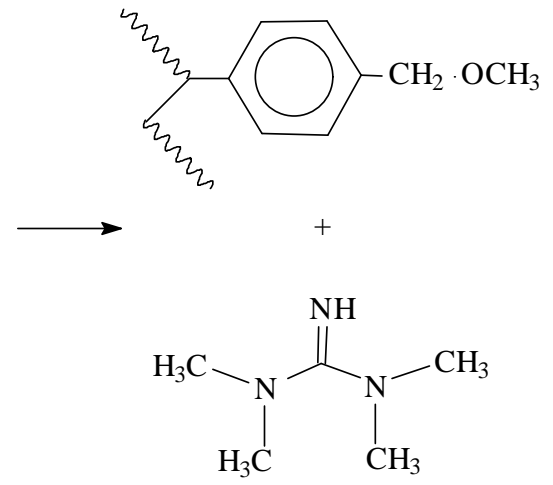

Scheme 13. Leaching of the guanidine moiety from the polymers.
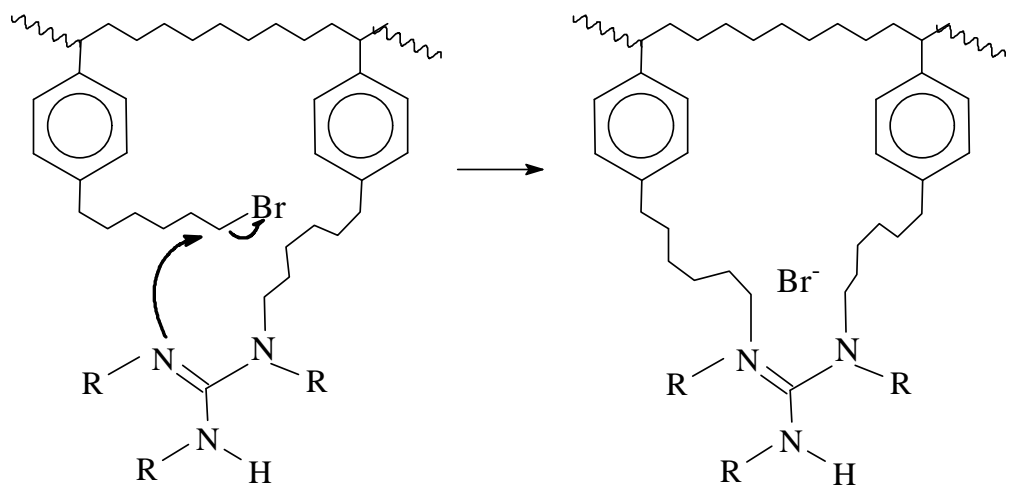

Scheme 14. Reaction of the heterogenized guanidines III-VI with unreacted 6-bromohexyl substituents. 


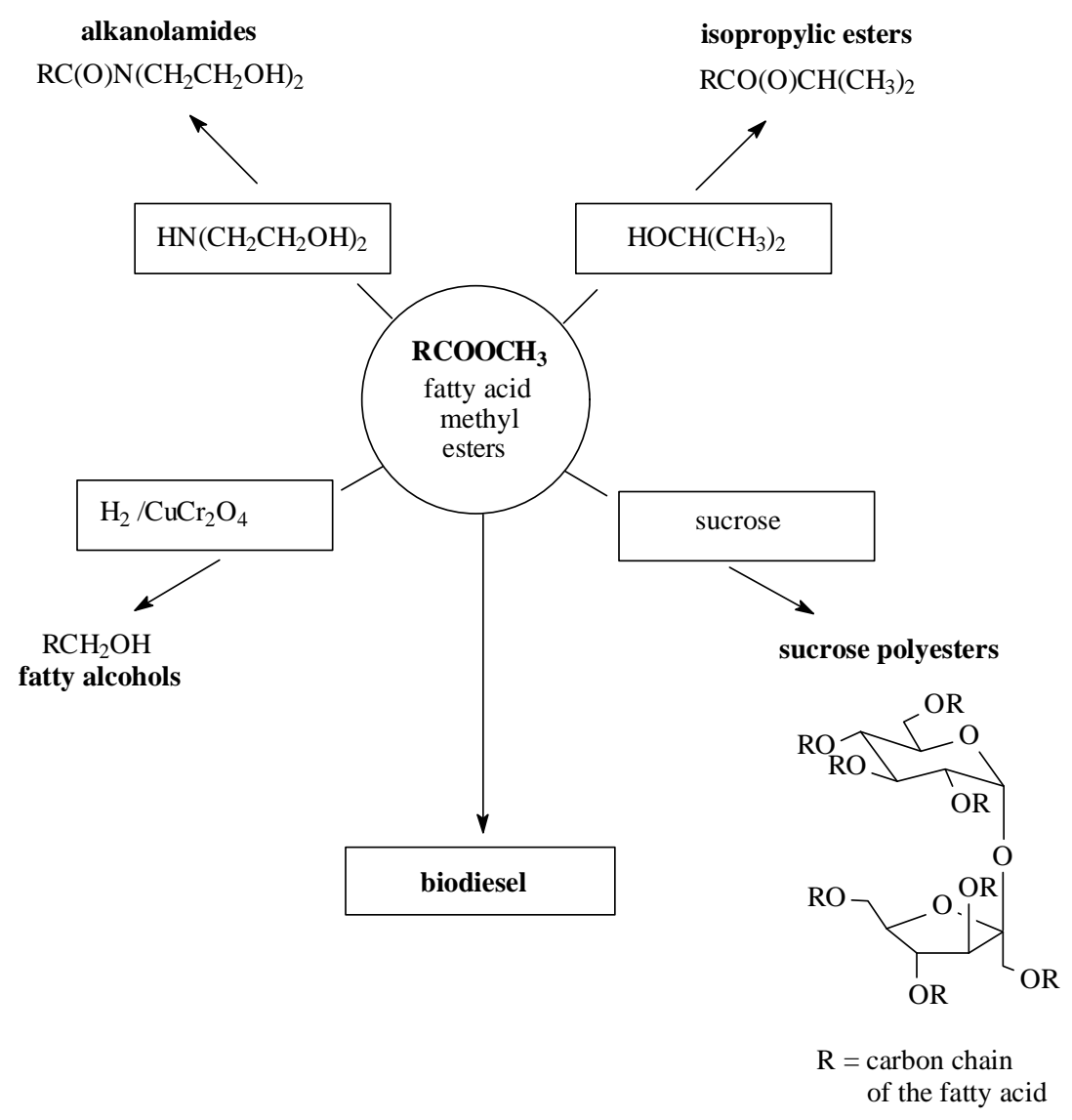

Scheme 15. Some fatty acid methyl esters applications.

alkyl resins, tobacco, explosives, cellulose processing, etc $^{81}$.

\section{Fatty Acid Alkyl Esters as Biodiesel}

With exception of hydroelectricity and nuclear energy, the major part of all energy consumed worldwide comes from petroleum, charcoal and natural gas. However, these sources are limited, and will be exhausted by the end of the next century ${ }^{33}$. Thus, looking for alternative sources of energy is of vital importance.

Vegetable oils are a renewable and potentially inexhaustible source of energy with an energetic content close to diesel fuel ${ }^{82}$. Historically, it is believed that Rudolf Diesel himself ${ }^{82}$ started research with respect to the use of vegetable oils as fuel for diesel engines. In the following decades, the studies became more systematic and, nowadays, much is known about its use as fuel. Despite energetically favorable, the direct use of vegetable oils in fuel engines is problematic. Due to their high viscosity (about 11 to 17 times higher than diesel fuel) and low volatility, they do not burn completely and form deposits in the fuel injector of diesel engines. Furthermore, acrolein (a highly toxic substance) is formed through thermal decomposition of glycerol $^{32,83-87}$. Different ways have been considered to reduce the high viscosity of vegetable oils:
- dilution of 25 parts of vegetable oil with 75 parts of diesel fuel ${ }^{32}$;

- microemulsions with short chain alcohols (e.g. ethanol or methanol) ${ }^{32}$;

- thermal decomposition, which produces alkanes, alkenes, carboxylic acids and aromatic compounds ${ }^{87}$;

- catalytic cracking, which produces alkanes, cycloalkanes and alkylbenzenes ${ }^{84}$, and

- transesterification with ethanol or methanol ${ }^{88,89}$.

Among all these alternatives, the transesterification seems to be the best choice, as the physical characteristics of fatty acid esters (biodiesel) are very close to those of diesel fuel ${ }^{32}$ and the process is relatively simple. Furthermore, the methyl or ethyl esters of fatty acids can be burned directly in unmodified diesel engines, with very low deposit formation $37,38,79,80,82$.

Several types of vegetable oils, with a diversified composition in fatty acids, can be used for the preparation of biodiesel. Soybean ${ }^{26,30,32,84}$, rapeseed $^{38,78,79}$, sunflower ${ }^{28}$ and palm ${ }^{29,37}$ oils are the most studied. However, there are no technical restrictions to the use of other types of vegetable oils. Considering the type of the alcohol, the use of methanol is advantageous as it allows the simultaneous separation of glycerol. The same reaction using ethanol is 
more complicated as it requires a water-free alcohol, as well as an oil with a low water content, in order to obtain glycerol separation.

Normally, methanol is used as it is the cheapest alcohol in most countries. However, in Brazil it is advantageous to use anhydrous ethanol ${ }^{90}$, which is already produced in large quantities to be mixed with gasoline. The guanidines described here have been shown to be efficient catalysts for the transesterification of vegetable oils with commercial anhydrous ethanol ${ }^{69}$.

\section{Fatty Acid Esters of Carbohydrates}

The fatty acid esters of carbohydrates can be obtained by esterification of fatty acids, or by transesterification of their correspondent alkyl esters with carbohydrates (or other polyols) and constitute an important class of synthetic organic products. Their physico-chemical properties, which depend on the number and type of the esterified fatty acid, allow their application as non-ionic biodegradable surfactants $^{74}$, or as substitutes of vegetable oils for noncalorific diets ${ }^{75-77}$. The mixture of hexa-, hepta- and octaesters of sucrose, known as "olestra", has been studied for more than 20 years ${ }^{75}$. Their physical properties are very close to those of the triglycerides with similar esterified fatty acids, and the resistance to the pancreatic lipase (which avoids the absorption by the digestive tract) allows its application as non-calorific edible oil ${ }^{75}$.

Typically, the sugar polyesters (SPE) are prepared through base-catalyzed transesterification of carbohydrates with fatty acid methyl esters, using sodium methoxide as catalyst ${ }^{91-95}$. However, some of these methods require very high temperatures (above $100{ }^{\circ} \mathrm{C}$ ) and toxic low-volatile solvents (e.g. DMF and DMSO), compromising the final product for human consumption. Alternatively, Rizzi and Taylor ${ }^{91}$, based on the studies of Feuge $e t$ $a l .{ }^{96}$, developed a two-stage solvent-free process, in which the SPE are synthesized by transesterification, using sodium hydride, Na-K alloy and soaps as catalyst. Despite the very good reaction yields (about 90\%), this process still shows some inconveniences such as the need for high temperatures $\left(150^{\circ} \mathrm{C}\right)$, and the difficulty to purify the final product (the soaps are not easily eliminated).

Another solvent-free process was proposed by Akoh and Swanson ${ }^{93}$, in which sorbitol and trealose octaoleate are produced in excellent yields (> 90\%) through interesterification reactions of the correspondent acetates and methyl oleate, using $\mathrm{Na}$ as catalyst. The temperature $\left(110^{\circ} \mathrm{C}\right)$ and reaction time $(2.5 \mathrm{~h})$ are lower when compared to the previous work. However, the catalyst requires a water-free system in order to avoid its deactivation.

New milder solvent-free catalytic systems are being developed, and consist in the use of guanidine as catalyst, which furnished good preliminary results ${ }^{97}$.

\section{Conclusions and Perspectives}

The industrial homogeneous catalysts will have to be substituted in the near future by heterogeneous catalysts due to environmental reasons. Good strong-base heterogeneous catalysts are still in development. One possibility would be the use of zeolites with strong basic sites ${ }^{98}$. Here the use of guanidines anchored on organic polymers was emphasized. To avoid leaching of the guanidine, however, it should be doubly anchored to the polymers. Another possibility would be the encapsulation of guanidines in an appropriate inorganic matrix. The $\mathrm{Y}$ zeolite is not appropriate for this purpose as the rather small diameter of its pore system slows down the diffusion of the fatty acid triglycerides.

\section{Acknowledgments}

The authors acknowledge financial support from FAPESP and fellowships from FAPESP and CNPq. Part of our work has been developed with financial support from the Commission of the European Communities.

\section{References}

1. Otera, J. Chem. Rev. 1993, 93, 1449.

2. Weissermel, K.; Arpe, H.-J. In Industrial Organic Chemistry, VCH Verlagsgesellschaft, $2^{\text {nd }}$ Ed., Weinhein, 1993, p 396.

3. Rehberg, C.E.; Fisher, C.H. J. Am. Chem. Soc. 1944, 66, 1203.

4. Rehberg, C.E.; Faucette, W.A.; Fisher, C.H. J. Am. Chem. Soc. 1944, 66, 1723.

5. Rehberg, C.E. Org. Synth. 1955, III, 146.

6. Haken, J.K. J. Appl. Chem. 1963, 13, 168.

7. Shishido, K.; Irie, O.; Shibuya, M. Tetrahedron Lett. 1992, 33, 4589.

8. Chavan, S.P.; Zubaidha, P.K.; Ayyangar, N.R. Tetrahedron Lett. 1992, 33, 4605.

9. Vatlas, I.; Harrison, I.T.; Tökés, L.; Fried, J.H.; Cross, A.D. J. Org. Chem. 1968, 33, 4176.

10. Narasaka, K.; Yamaguchi, M.; Mukaiyama, T. Chem. Lett. 1977, 959.

11. Taft, R.W. Jr.; Newman, M.S.; Verhoek, F.H. J. Am. Chem. Soc. 1950, 72, 4511.

12. Billman, J.H.; Smith, W.T. Jr.; Rendall, J.L. J. Am. Chem. Soc. 1947, 69, 2058.

13. Haken, J.K. J. Appl. Chem. 1966, 16, 89.

14. Frank, R.L.; Davis, H.R. Jr.; Drake, S.S.; McPherson, J.B. Jr. J. Am. Chem. Soc. 1944, 66, 1509.

15. Wulfman, D.S.; McGiboney, B.; Peace, B.W. Synthesis 1972, 49.

16. Rossi, R.A.; de Rossi, R.H. J. Org. Chem. 1974, 39, 855.

17. Rehberg, C.E.; Fisher, C.H. J. Org. Chem. 1947, 12, 226. 
18. Said, A. Chimia 1974, 28, 234.

19. Brenner, M.; Huber, W. Helv. Chem. Acta. 1953, 36, 1109.

20. Seebach, D.; Hungerbühler, E.; Naef, R.; Schnurrenberger, P.; Weidmann, B.; Züger, M. Synthesis 1982, 138.

21. Imwinkelried, R.; Schiess, M.; Seebach, D. Org. Synth. 1987, 65, 230.

22. Blandy, C.; Gervais, D.; Pellegatta, J.-L.; Gillot, B.; Guiraud, R. J. Mol. Catal. 1991, 64, L1-L6.

23. Pereyre, M.; Colin, G.; Delvigne, J.-P. Bull. Soc. Chim. Fr. 1969, 262.

24. Otera, J.; Yano, T.; Atsuya, K.; Nosaki, H. Tetrahedron Lett. 1986, 27, 2383.

25. Wright, H.J.; Segur, J.B.; Clark, H.V.; Coburn, S.K.; Langdon, E.E.; DuPuis, E.N. Oil \& Soap 1944, 145.

26. Freedman, B.; Butterfield, R.O.; Pryde, E.H. J. Am. Oil Chem. Soc. 1986, 63, 1375.

27. Stern, R.; Hillion, G.; Eur. Pat. Appl. EP 356,317 (Cl. C07C67/56), 1990; Chem. Abstr. 113: P58504k (1990).

28. Harrington, K.J.; D’Arcy-Evans, C. Ind. Eng. Chem. Prod. Res. Dev. 1985, 24, 314.

29. Graille, J.; Lozano, P.; Pioch, D.; Geneste, P. Oléagineux 1986, 41, 457.

30. Freedman, B.; Pryde, E.H.; Mounts, T.L. J. Am. Oil Chem. Soc. 1984, 61, 1638.

31. Stoffel, W.; Chu, F.; Ahrens, E.H. Jr. Anal. Chem. 1959, 31, 307.

32. Schwab, A.W.; Baghy, M.O.; Freedman, B. Fuel 1987, 66, 1372.

33. Aksoy, H.A.; Becerik, I.; Karaosmanoglu, F.; Yamaz, H.C.; Civelekoglu, H. Fuel 1990, 69, 600.

34. Tanaka, Y.; Okabe, A.; Ando, S. US. Pat. Appl. 4,303,590 (Cl. C11C3/02), 1981; Chem. Abstr. 94: P 139250r (1981).

35. Gaskoks-Vertrieb GmbH; Austrian AT 387,399 (Cl.C11C3/04), 1989; Chem. Abstr. 110: P196201y (1989).

36. Wimmer, T. PCT. Ind. Appl. WO 9309,212 (Cl C11C3/04), 1993; Chem. Abstr. 120: P10719b (1994).

37. Graille, J.; Lozano, P.; Pioch, D.; Geneste, P. Oléagineux 1985, 40, 271.

38. Filip, V.; Zajic, V.; Smidrkal, J. Rev. Fr. Corps Gras 1992, 39, 91.

39. Bajwa, U.; Bains, G.S. J. Food. Sci. Technol. 1987, 24,81 .

40. Guthrie, J.P. J. Am. Chem. Soc. 1991, 113, 3941.

41. Drauz, K.; Waldmann, H.; Sauerbrei, B. In Applied Homogeneous Catalysis with Organometallic Compounds; Cornils, B.; Herrmann, W.A., ed.; vol. 2, VCH Verlagsgessellschaft, Weinheim, 1996, p 769.

42. Posorske, L.H. J. Am. Oil Chem. Soc. 1984, 61, 1758.
43. Posorske, L.H.; Le Febvre, G.K.; Miller, C.A.; Hansen, T.T.; Glenvig, B.L. J. Am. Oil Chem. Soc. 1988, 65, 922.

44. McNeill, G.P.; Shimizu, S.; Yamane, T. J. Am. Oil Chem. Soc. 1991, 68, 1.

45. McNeill, G.P.; Yamane, T. J. Am. Oil Chem. Soc. 1991, 68, 6.

46. Elliot, J.M.; Parkin, K.L. J. Am. Oil Chem. Soc. 1991, 68, 171.

47. Matsumoto, W.; Nezu, T.; Ogata, H.; Kobori, S.; Suzuki, K. Jpn. Kokai Tokkyo Koho, JP 0601,996 9401,996] (Cl.C11C3/10), 1994; Chem. Abstr. 120: P247778h (1994).

48.Zaks, A.; Gross, A.T. PCT Int. Appl. WO 9004,033 (Cl.C12P7/64), 1990; Chem. Abstr. 113: P76643j (1990).

49. Resck, I.S. Química Nova 1994, 17, 317.

50.Höfle, G.; Steglich, W.; Vorbrüggen, H. Angew. Chem. Int. Ed. Engl. 1978, 17, 569.

51. Schwesinger, R. Chimia 1985, 39, 269.

52. Taber, D.F.; Amedio, J.C.; Patel, Y.K. J. Org. Chem. 1985, 50, 3618.

53. Oediger, H.; Möller, F.; Eiter, K. Synthesis 1972, 591.

54. McKay, A.F.; Kreling, M. -E. Can. J. Chem. 1957, 35, 1438.

55.Pollini, G.P.; Barco, A.; De Giuli, G. Synthesis 1972, 44.

56. Andruszkiewicz, R.; Silverman, R.B. Synthesis 1989, 953.

57. Flynn, K.G.; Nenortas, D.R. J. Org. Chem. 1963, 28, 3527.

58. Barcelo, G.; Grenouillat, D.; Senet, J.-P.; Sennyey, G. Tetrahedron 1990, 46, 1839.

59. Khorana, H.G. Chem. Rev. 1953, 53, 145.

60. Smith, P.A.S. In The Chemistry of the Open Chain Nitrogen Compounds; Benjamin; New York, 1965, vol.1, cap. VI, p 277.

61. Kurzer, F.; Sanderson, P.M. J. Chem. Soc. 1962, 230.

62. Short, J.H.; Biermacher, U.; Dunnigan, D.A.; Leth, T.D. J. Med. Chem. 1963, 6, 275.

63. Vargas, R.M. D.Sc. Thesis, Universidade Estadual de Campinas, Campinas, Brazil, 1996.

64. Schuchardt, U.; Vargas, R.M.; Gelbard, G. J. Mol. Catal. 1995, 99, 65.

65. Angyal, S.J.; Warburton, W.K. J. Chem. Soc. 1951, 2492.

66.Xavier, C.P.M.; Sercheli, R.; Vargas, R.M.; Schuchardt, U. $9^{\circ}$ Congresso Brasileiro de Catálise (Instituto Brasileiro de Petróleo, 1997) accepted for publication.

67. Schuchardt, U.; Lopes, O.C. BR 8202 429, 1984; Chem. Abstr. 101: P93246 (1984). 
68. Schuchardt, U.; Lopes, O.C. Anais do XI Simpósio Ibero-Americano de Catálise (Instituto Mexicano del Petroleo, Guanajuato, 1988) p 1505.

69. Schuchardt, U.; Lopes, O.C. Anais do I Simpósio Nacional sobre Fontes Novas e Renováveis de Energia (MCT, Brasília, 1988) p 51.

70. Schuchardt, U.; Vargas, R.M.; Gelbard, G. J. Mol. Catal. 1996, 109, 37.

71. Sercheli, R.; Ferreira, A.L.B.; Guerreiro, M.C.; Vargas, R.M.; Sheldon, R.A.; Schuchardt, U. Tetrahedron Lett. 1997, 38, 1325.

72. Sercheli, R.; Ferreira, A.L.B.; Vargas, R.M.; Schuchardt, U. In preparation.

73. Farris, R.D. J. Am. Oil Chem. Soc. 1979, 56, 770A.

74. Donnelly, M.J.; Bu'Lock, J.D. J. Am. Oil Chem. Soc. 1988, 65, 284.

75. Jandacek, R.J. Chemtech 1991, 398.

76. Jandacek, R.J. J. Chem. Ed. 1991, 68, 476.

77. Akoh, C.C.; Swanson, B.G. J. Am. Oil Chem. Soc. 1989, 66, 1581.

78. Peterson, G.R.; Scarrah, W.P. J. Am. Oil Chem. Soc. 1984, 61, 1593 .

79. Mittelbach, M.; Tritthard, P. J. Am. Oil Chem. Soc. 1988, 65, 1185.

80. Staat, F.; Vermeersch, G. Rev. Fr. Corps Gras 1993, $5 / 6,167$.

81. Kirk-Othmer. In Encyclopedia of Chemical Technology; John Wiley \& Sons; 3rd Ed., New York, 1980, vol. 11, p 921.

82. Zaher, F.A. Grasas y Aceites 1990, 41, 82.

83. Gateau, P.; Guibet, J.C. Rev. Inst. Fr. Pét. 1985, 40, 509.
84. Rocha Filho, G.N.; Brodzki, D.; Djéga-Mariadassou, G. Fuel 1993, 72, 543.

85. Pryde, E.H. J. Am. Oil Chem. Soc. 1984, 61, 1609.

86. Peterson, C.L.; Auld, D.L.; Korus, R.A. J. Am. Oil Chem. Soc. 1983, 60, 1579.

87. Schwab, A.W.; Dykstra, G.J.; Selke, E.; Sorenson, S.C.; Pryde, E.H. J. Am. Oil Chem. Soc. 1988, 65, 1781 .

88. Freedman, B.; Butterfield, R.O.; Pryde, E.H. J. Am. Oil Chem. Soc. 1985, 62, 662.

89. Freedman, B.; Kwolek, W.F.; Pryde, E.H. J. Am. Oil Chem. Soc. 1985, 62, 663.

90. Schuchardt, U.; Lopes, O.C. Anais do $3^{\circ}$ Congresso Brasileiro de Energia (IBP, Rio de Janeiro, 1984) p 1620.

91. Rizzi, G.P.; Taylor, H.M. J. Am. Oil Chem. Soc. 1978, $55,398$.

92. Aguiar, L.M.G.; Silva, G.A.; Silva, C.M.A.; Ferreira, E.B. $17^{\mathrm{a}}$ Reunião Anual da Sociedade Brasileira de Química, (SBQ, Caxambu, 1994) abstract QO-118.

93. Weiss, T.J.; Brown, M.; Zeringue, H.J.; Feuge, R.O. J. Am. Oil Chem. Soc. 1971, 48, 145.

94. Weiss, T.J., Brown, M., Zeringue, H.J., Feuge, R.O. J. Am. Oil Chem. Soc. 1972, 49, 524.

95. Mattson, F.H.; Nolen, G.A. J. Nutr. 1972, 102, 1171.

96. Feuge, R.O.; Zeringue, H.J.; Weiss, T.J.; Brown, M. J. Am. Oil Chem. Soc. 1970, 47, 56.

97. Vargas, R.M. In preparation.

98. Wallau, M.; Schuchardt, U. J. Braz. Chem. Soc. 1995, $6,393$.

FAPESP helped in meeting the publication costs of this article 